\title{
Kinetic Study of the Atmospheric Oxidation of a Series of Epoxy Compounds by $\mathrm{OH}$ Radicals
}

Carmen Maria Tovar, ${ }^{* 1}$ Ian Barnes ${ }^{1 \dagger}$, Iustinian Gabriel Bejan*2 ${ }^{* 2}$ and Peter Wiesen ${ }^{1}$

$5{ }^{1}$ Institute for Atmospheric and Environmental Research, University of Wuppertal, Wuppertal, 42097, Germany

2“Alexandru Ioan Cuza" University of Iasi, Faculty of Chemistry and Integrated Center of Environmental Science Studies in the North-Eastern Region - CERNESIM, Iasi, 700506, Romania

${ }^{\dagger}$ deceased, on January 1, 2018

Correspondence to: Carmen Maria Tovar (carmen.tovar ramos@uni-wuppertal.de) and Iustinian Gabriel Bejan

10 (iustinian.bejan@uaic.ro)

\begin{abstract}
The kinetics of the gas-phase reactions of hydroxyl radicals with cyclohexene oxide (CHO), 1,2-epoxyhexane (EHX), 1,2-epoxybutane (12EB), trans-2,3-epoxybutane ( $t \mathrm{~EB})$ and cis-2,3-epoxybutane ( $c \mathrm{~EB}$ ) have been investigated using the relative rate technique. The experiments have been performed at $(298 \pm 3) \mathrm{K}$ and $(760 \pm 10)$ Torr total pressure of synthetic

15 air using different reference compounds in a 10801 Quartz Reactor (QUAREC) and a 4801 Duran glass chamber. The following room temperature rate coefficients $\left(\mathrm{cm}^{3}\right.$ molecule $\left.{ }^{-1} \mathrm{~s}^{-1}\right)$ were obtained: $\mathrm{k}_{1}(\mathrm{OH}+\mathrm{CHO})=(5.93 \pm 1.78) \times 10^{-12}, \mathrm{k}_{2}(\mathrm{OH}+\mathrm{EHX})=$ $(5.77 \pm 1.29) \times 10^{-12}, \mathrm{k}_{3}(\mathrm{OH}+12 \mathrm{~EB})=(1.98 \pm 0.39) \times 10^{-12}, \mathrm{k}_{4}(\mathrm{OH}+c \mathrm{~EB})=(1.50 \pm 0.26) \times 10^{-12}, \mathrm{k}_{5}(\mathrm{OH}+t \mathrm{~EB})=(1.81 \pm 0.42) \times$ $10^{-12}$. With the exception of previous studies for 1,2-epoxybutane and cyclohexene oxide, this is to the best of our knowledge the first kinetic study of the reaction of these compounds with $\mathrm{OH}$ radicals. Atmospheric lifetimes, reactivity trends and atmospheric implications are discussed considering the epoxy compound rate coefficients obtained in the present study. In addition to a direct comparison with the literature data where possible, the results from the present study are compared with values estimated from the Structure Activity Relationship method.
\end{abstract}

\section{Introduction}

Oxygenated volatile organic compounds (OVOCs) play an important role in atmospheric chemistry and have an impact on climate and human health (Calvert et al., 2011). From those OVOCs emitted from either biogenic or anthropogenic sources, cyclic ethers, with the exception of furans (Villanueva et al., 2009; Li et al., 2018) have received very little attention. Epoxides, as simplest cyclic ethers, are an important and valuable class of raw materials and intermediates for chemical industry. They can polymerize for the production of homo- and copolymers as polyethers, polyols and polycarbonates (Hereijgers et al., 2012). Epoxides are considered a key element in "click-chemistry" (Kolb et al., 2001; Fokin and Wu, 2006). They are also relevant 
30 in the field of pharmaceutical applications because of their potential as protease inhibitors against several diseases like cancer, stroke, and parasitic or viral diseases (Powers et al., 2002; Otto and Schirmeister, 1997; Schirmeister and Klockow, 2003). A relatively new utilization of epoxides, which could have huge atmospheric implications and an impact on climate change is their potential use for carbon capture and storage, i.e. the chemical fixation of $\mathrm{CO}_{2}$ in the form of cyclic carbonates in the presence of various catalysts (Zou and Hu, 2017; Zhang et al., 2020; Guo et al., 2021; Andrea and Kerton, 2021; Appaturi et

35 al., 2021).

Epoxides are known to be formed from the reaction of $\mathrm{O}\left({ }^{3} \mathrm{P}\right)$ with isoprene at nearly $80 \%$ yield (Atkinson et al., 1994b; Paulson et al., 1992). In the atmospheric ozonolysis of isoprene epoxide yields of about 2-3\% have been observed (Atkinson et al., 1994a). A few percent of epoxide formation have been reported from $\alpha$-pinene ozonolysis as well as from the reaction of $1,2-$ dimethyl-1-cyclohexane with ozone (Alvarado et al., 1998). Atkinson (Atkinson et al., 1994a) concluded that epoxides

40 formation is a process occurring in the ozonolysis of most terpenes and cycloalkenes. Low yields of isoprene derived epoxides have been observed also from the gas phase nitration of isoprene (Skov et al., 1994).

Furthermore, in indoor pollution studies the formation of epoxides from the heterogeneous oxidation of VOCs with gas phase ozone has been reported (Zhou et al., 2017). Other compounds could also form epoxides during their gas phase chemical degradation by $\mathrm{OH}$ radicals and ozone. More recent theoretical and mechanistic studies report epoxide formation during the gas phase ozonolysis of methylbutenol and sabinene via the Criegee degradation mechanism (Calvert et al., 2000; Almatarneh et al., 2019a, b).

Epoxides are responsible for up to $10 \%$ of the open ring products from the degradation of aromatic hydrocarbons in the presence of $\mathrm{OH}$ radicals according to the MCM model (Master Chemical Mechanism) (Jenkin et al., 2015). In the past, benzene oxide has been reported as an epoxide type product in the reaction of benzene with OH radicals (Klotz et al., 1997, 2000).

50 Besides, a theoretical study has reported epoxide formation in the $\mathrm{OH}$ radical initiated oxidation of dimethylphenol isomers (Sandhiya et al., 2013).

Secondary organic aerosols (SOA) constitute a substantial portion of the total ambient aerosol particles, which are mainly originating from biomass burning and atmospheric reactions of volatile organic compounds (VOCs) (Kanakidou et al., 2005). Epoxides can polymerize easily, leading to the growth of SOA (Gao et al., 2004). A recent study shows that the yield of

55 epoxides from the reaction of aromatic compounds with $\mathrm{OH}$ radicals is probably dependent on the abundance of $\mathrm{NO} \mathrm{HO}_{2}$ and $\mathrm{RO}_{2}$ in the reaction system (Vereecken, 2018). This aspect represents an uncertainty in atmospheric models to reliably estimate the expected SOA formation from reactive epoxide uptake by aerosols (Paulot et al., 2009). The presence of epoxides in SOA are highly probable for conditions prevailing in the atmosphere leading to higher hygroscopicity of particles with potential cloud condensation nuclei activity by conversion to organosulfates through an acid catalysed mechanism (Fuzzi et al., 2015).

60 Isoprene derived epoxides are very important intermediates, which could explain at least in part the composition of ambient SOA both in urban areas (Lin et al., 2013) and remote regions (Jacobs et al., 2013; Stropoli et al., 2019; Paulot et al., 2009; Jacobs et al., 2013; Shrivastava et al., 2019). 
The toxicity of ultrafine particles such as SOA is not only related to their atmospheric concentration but also to the nature and chemical properties of both the precursors and the formed SOA components (Jiang et al., 2019). In this sense, epoxides are of great concern because the epoxy functional group can act as an electrophile in its interaction with DNA and nucleosides, producing carcinogenic and mutagenic damages (Ehrenberg and Hussain, 1981).

The kinetic and mechanistic database available on the gas-phase reactions of epoxy compounds with the atmospheric oxidants $\mathrm{OH}$ and $\mathrm{NO}_{3}$ radicals, $\mathrm{O}_{3}$, and chlorine atoms are very scarce. For the compounds investigated in the present study, there is only one previous relevant study towards chlorine atoms at 298K (Tovar et al., 2021) . Two studies have reported the rate coefficients of the reaction of 1,2-epoxybutane towards OH radicals (Wallington et al., 1988a; El Othmani et al., 2021a) and more recently cyclohexene oxide with $\mathrm{OH}$ radicals have been measured as a function of temperature (El Othmani et al., 2021a). In the present study we have performed for the first time a kinetic study of the reaction of $\mathrm{OH}$ radicals with 1,2-epoxyhexane, trans-2,3-epoxybutane and cis-2,3-epoxybutane at $298 \mathrm{~K}$ using the relative rate method.

Since several of the rate coefficients for the reactions of epoxides with $\mathrm{OH}$ radicals have been measured in the present study

75 for the first time and cannot be compared with literature values accordingly, we have applied different approaches for the estimation of structure-activity relationship (SARs) for the compounds studied in this work.

\section{Methods}

The experiments were performed in two different environmental chambers, namely a $1080 l$ quartz-glass photoreactor and a $480 l$ Duran glass chamber. These two photoreactors are briefly described below.

\section{$80 \quad 2.1480$ l reactor}

This reaction chamber consists of a cylindrical Duran glass vessel ( $3 \mathrm{~m}$ length, $45 \mathrm{~cm}$ dia.) closed at both ends by Teflon coated aluminium end flanges. Integrated on the metal flanges are ports for the inlet of reactants into the chamber and for the collection of samples from the reaction mixtures for further analyses. Other accessories, like a mixing fan to ensure homogeneity of the reaction mixtures and a capacitance manometer, are also located on the flanges. Arranged concentrically around the outside of the reactor are 32 super actinic fluorescent lamps (Philips TLA $40 \mathrm{~W}, 300 \leq \lambda \leq 460 \mathrm{~nm}, \lambda_{\max }=360 \mathrm{~nm}$. The vacuum (ca. $10^{-}$ ${ }^{3} \mathrm{mbar}$ ) is maintained by means of a Leybold turbo-molecular pump, model RUVAC WZ $151\left(500 \mathrm{~m}^{3} / \mathrm{h}\right)$, backed by a Leybold double stage rotary fore pump, model D40B $\left(200 \mathrm{~m}^{3} / \mathrm{h}\right)$. A White-type mirror system mounted inside the reactor is set to an overall optical path length of $51.6 \mathrm{~m}$. The analysis of the reactants was done, during the experiments by in situ FTIR (Fourier Transform Infrared) long path spectroscopy using a resolution of $1 \mathrm{~cm}^{-1}$. The FTIR spectrometer (Nicolet Magna 520) and the transfer mirror system are covered with a protective box and are permanently purged with dry air to remove water vapour. The spectrometer is directly controlled by the OMNIC software, which is provided by Nicolet. 


\subsection{1 reactor}

A detailed description of the reactor can be found in the literature (Barnes et al., 1994). Briefly, the reactor consists of the two quartz glass tubes with an inner diameter of $47 \mathrm{~cm}$ and a wall thickness of $5 \mathrm{~mm}$. The reactor has a total length of $6.2 \mathrm{~m}$.

95 Silicone rubber rings are used for all the glass-metal connections as well as for metal-metal connections. The reactor is connected to a turbo molecular pump system by which an end vacuum of $10^{-3} \mathrm{mbar}$ can be achieved. A total of three fans are used for homogeneous mixing of compounds within the reactor. Different types of inlets are mounted on the end flanges for the introduction of chemicals and for pressure measurements.

The beam from an FT-IR spectrometer is coupled via a transfer mirror system into the reactor through $\mathrm{KBr}$ windows located in one of the end flanges. A White-type mirror system (base path length (5.91 \pm 0.01$) \mathrm{m}$ ), mounted inside the reactor, is used for multiple-reflection of the infrared beam within the reactor before it reaches the detector. Reactants were monitored in situ in the reactor in the infrared using 82 traverses of the beam, which is equivalent to a total optical path length of $(484.7 \pm 0.8)$ $\mathrm{m}$. All spectra in this work were recorded with a spectral resolution of $1 \mathrm{~cm}^{-1}$. The FT-IR spectrometer NICOLET NEXUS was used, which is equipped with a liquid nitrogen cooled (77 K) mercury-cadmium-tellurium (MCT) detector. A Globar was used as IR light source. All mirrors are gold coated to achieve optimum reflectivity.

Two different types of lamps (32 each) are installed around the reactor. They are mounted alternatively around the reactor to ensure homogeneity of the light intensity within the reactor. The first type, 32 superactinic fluorescent lamps (Philips TL05 40W: 300- $460 \mathrm{~nm}$, max. intensity at ca. $360 \mathrm{~nm}$ ) and 32 low-pressure mercury vapour lamps (Philips TUV 40W: max. intensity at $254 \mathrm{~nm}$ ) can be used to irradiate the reaction mixture.

110 Typically, 64 interferograms were co-added per spectrum over a period of approximately 1 minute and 15-20 such spectra were recorded per experiment.

\subsection{Relative Rate Method}

The relative rate method was used to determine the rate constant of the $\mathrm{OH}$ radical induced oxidation of the epoxy compounds. The photolysis of $\mathrm{CH}_{3} \mathrm{ONO}$ in the presence of $\mathrm{NO}$ was used for the production of $\mathrm{OH}$ radicals:

115

$$
\begin{gathered}
\mathrm{CH}_{3} \mathrm{ONO}+\mathrm{h} v(\lambda \sim 360 \mathrm{~nm}) \rightarrow \mathrm{CH}_{3} \mathrm{O}+\mathrm{NO} \\
\mathrm{CH}_{3} \mathrm{O}+\mathrm{O}_{2} \rightarrow \mathrm{CH}_{2} \mathrm{O}+\mathrm{HO}_{2} \\
\mathrm{HO}_{2}+\mathrm{NO} \rightarrow \mathrm{NO}_{2}+\mathrm{HO}
\end{gathered}
$$

120 Reaction mixtures consisting of a reference organic compound, the sample organic reactant and the radical precursor compounds, diluted in synthetic air, were prepared in the reaction chamber and left for mixing prior to photolysis for approximately $15 \mathrm{~min}$. Known amounts of the reagents were flushed into the reaction chamber by a stream of nitrogen or synthetic air and the reactor was then filled with synthetic air to atmospheric pressure. 
Typical photolysis times ranged from 15 to $20 \mathrm{~min}$. In the presence of the $\mathrm{OH}$ radical the corresponding epoxide and reference compound are consumed by the following reactions:

$$
\begin{array}{cccc}
\mathrm{OH}+\text { Epoxides } & \rightarrow & \text { Products } & \left(k_{\text {Epoxide }}\right)(1) \\
\mathrm{OH}+\text { Reference } & \rightarrow & \text { Products } & \left(k_{\text {Reference }}\right)(2)
\end{array}
$$

130 Provided that the reference compound and the epoxide are lost only by reactions (1) and (2), then it can be shown that:

$$
\ln \left\{\frac{[\text { Epoxide }]_{0}}{[\text { Epoxide }]_{t}}\right\}=\frac{k_{\text {Epoxide }}}{k_{\text {Reference }}} \ln \left\{\frac{[\text { Reference }]_{0}}{[\text { Reference }]_{t}}\right\}(\mathrm{I})
$$

where, $[\text { Epoxide }]_{0},[\text { Reference }]_{0}$, [Epoxide $]_{\mathrm{t}}$ and $[\text { Reference }]_{\mathrm{t}}$ are the concentrations of the corresponding epoxy compound and reference compound at times $t=0$ and $t$, respectively and $k_{\text {Epoxide }}$ and $k_{\text {Reference. }}$ are the rate coefficients of reactions (1) and (2), respectively.

In order to test for a possible loss of the reactants through photolysis, mixtures of the reactants in air in the absence of methyl nitrite were irradiated for $30 \mathrm{~min}$ and photolysis were found to be negligible for both the epoxide and the reference compounds. Additionally, various tests were performed to assess possible loss of the reactants via deposition on the chamber walls, and no

140 significant wall loss of the epoxy compounds and references was observed leaving the compounds in the dark in the reactor. A minimum of two experiments for each epoxide compound has been performed in this study and up to three references compounds have been used. Reference compounds have been chosen based on similar reactivity as epoxides and suitability for FTIR subtraction procedures. Conversion of epoxides and reference compounds through the reaction with $\mathrm{OH}$ radical has been achieved up to 50\%. Initial mixing ratios used in the $1080 l$ reactor for the epoxides and reference compounds have been

145 as follow (in ppmv with $1 \mathrm{ppmv}=2.46 \times 10^{13}$ molecule $\mathrm{cm}^{-3}$ at $298 \mathrm{~K}$ and 760 Torr of total pressure of synthetic air): epoxides between 3-6 ppmv and reference compounds between 1 and 4 ppmv as shown in Table 1. Concentrations used for the reactions performed in 4801 reactor have been up to 8 times higher. Around 8 ppmv $\mathrm{CH}_{3} \mathrm{ONO}$ has been added in 10801 reactor and up to 10 times more in 4801 reactor.

All epoxy and reference compounds used in this study were obtained from Sigma Aldrich and used without further purification.

150 The stated purities were as follows: cyclohexene oxide, 98\%; 1,2-epoxyhexane, 97\%; 1,2-epoxybutane, 99\%; trans-2,3epoxybutane,97\%; for cis-2,3-epoxybutane, 97\%; propylene, 99\%; butane, 99\%; iso-propyl acetate, 99.6\%; sec-butyl acetate, 99\%; ethylene, $99.5 \%$ and $99.985 \%$ for synthetic air, respectively, which was from Messer.

155 Table 1. Initial mixing ratios used in the 10801 reactor and 4801 reactor for the epoxide and reference compounds in ppmv $(1 \mathrm{ppm}=2.46$ $\mathrm{x} 10^{13}$ molecule $\mathrm{cm}^{-3}$ ) at $298 \mathrm{~K}$ and 760 Torr of total pressure. 


\begin{tabular}{ccc}
\hline Initial mixing ratios $(\mathbf{p p m v})$ & Reactor $(\mathbf{1 0 8 0 ~ L )}$ & Reactor $(\mathbf{4 8 0 L})$ \\
\hline Epoxides & 6 & 17 \\
cyclohexene oxide & 6 & 28 \\
1,2-epoxyhexane & 6 & 23 \\
1,2-epoxybutane & 3 & 28 \\
cis-2,3-epoxybutane & 3 & 23 \\
trans-2,3-epoxybutane & & \\
Reference compounds & 4 & 8 \\
propylene & 4 & - \\
butane & 1 & 9 \\
iso-propyl acetate & 1 & 9 \\
sec-butyl acetate & 4 & 21 \\
ethylene & 8 & 84 \\
methyl nitrite & & \\
\hline
\end{tabular}

\section{Results and Discussion}

The experimental data from the kinetic experiments are plotted according to equation (I). Figure 1 shows the results obtained for the rate coefficient determinations from the $\mathrm{OH}$ radical initiated oxidation of: cyclohexene oxide using ethylene, propylene and isobutene as reference compounds; 1,2-epoxyhexane using ethylene and propylene as reference compounds; 1,2epoxybutane using ethylene and iso-propyl acetate as reference compounds; trans-2,3-epoxybutane using sec-butyl acetate, ethylene and propylene as reference compounds, and cis-2,3-epoxybutane using sec-butyl acetate, iso-propyl acetate and butane as reference compounds. All plots showed very good linearity despite the difficulties from handling the epoxides and subtracting the IR spectra.

The rate coefficients $\mathrm{k}_{\text {Epoxide }}$ given in Table 2 were put on an absolute basis using the following values for the reactions of the reference compounds $\left(\mathrm{cm}^{3}\right.$ molecule $\left.{ }^{-1} \mathrm{~s}^{-1}\right): \mathrm{k}\left(\mathrm{OH}+\right.$ propene): $(2.44 \pm 0.37) \times 10^{-11}$ (IUPAC Task Group on Atmospheric Chemical

170 Kinetic Data Evaluation, 2021), k(OH+ethylene): $(8.52 \pm 0.13) \times 10^{-12}$ (Calvert et al., 2015), k(OH+isobutene): $(5.10 \pm 1.33) \times$ $10^{-11}$ (IUPAC Task Group on Atmospheric Chemical Kinetic Data Evaluation, 2021), k(OH+iso-propyl acetate): (3.72 \pm 0.29$)$ $\times 10^{-12}$ (Wallington et al., 1988c), $\mathrm{k}\left(\mathrm{OH}+\right.$ sec-butyl acetate): $(5.65 \pm 0.59) \times 10^{-12}$ (Wallington et al., 1988c), $\mathrm{k}(\mathrm{OH}+$ butane): $(2.38 \pm 0.24) \times 10^{-12}$ (McGillen et al., 2020).

The rate coefficients obtained by using two simulation chambers are in perfect agreement as shown in Figure 2, which is a comparison of the data for EHX using propylene as reference compounds. The similar linearity has been observed for other 
compounds in both reactors. Accordingly, the data have been plotted together for all the epoxides regardless the reactor where the experiment has been performed.

The rate coefficient ratios $k_{\text {Epoxide }} / k_{\text {Reference }}$ obtained from linear regression analyses of these plots are summarized in Table 2. The rate coefficients are averages from the experiments with each reference compound from the experiments performed in

both reactors $\left(\mathrm{cm}^{3}\right.$ molecule $\left.{ }^{-1} \mathrm{~s}^{-1}\right): k_{1}(\mathrm{OH}+\mathrm{CHO})=(5.93 \pm 1.78) \times 10^{-12}, k_{2}(\mathrm{OH}+\mathrm{EHX})=(5.77 \pm 1.29) \times 10^{-12}, k_{3}(\mathrm{OH}+12 \mathrm{~EB})=$ $(1.98 \pm 0.39) \times 10^{-12}, k_{4}(\mathrm{OH}+c \mathrm{~EB})=(1.50 \pm 0.26) \times 10^{-12}, k_{5}(\mathrm{OH}+t \mathrm{~EB})=(1.81 \pm 0.42) \times 10^{-12}$.

Since all rate coefficients obtained in this study, except those for 12EB and CHO, were measured for the first time; the errors quoted for the rate coefficients include the $2 \sigma$ statistical error from the linear regression analyses for $k_{\text {Epoxide }} / \mathrm{k}_{\text {Reference }}$ ratios and up to $35 \%$ contribution in the recommended values of the rate coefficients for reference compounds with $\mathrm{OH}$ radicals. The ratios $\mathrm{k}_{\text {Epoxide }} / \mathrm{k}_{\text {Reference }}$ given in Table 2 could be used for future re-evaluation of the corresponding epoxides rate coefficients if the reference compounds rate coefficients would change.

Table 2. Measured rate coefficient ratios, $\mathrm{k}_{\text {Epoxide }} / \mathrm{k}_{\text {Reference., }}$ and the rate coefficients for the reactions of $\mathrm{OH}$ radical with epoxides at $(298 \pm 3$ ) $\mathrm{K}$ derived from these ratios.

\begin{tabular}{|c|c|c|c|}
\hline Epoxide & $\begin{array}{l}\text { Reference } \\
\text { compound }\end{array}$ & $\mathbf{k}_{\text {Epoxide }} / \mathbf{k}_{\text {Reference. }}$ & $\begin{array}{c}\mathbf{k}_{\text {Epoxide }} \\
\left(\mathrm{cm}^{3} \text { molecule }^{-1} \mathbf{s}^{-1}\right)\end{array}$ \\
\hline $\mathrm{CHO}$ & $\begin{array}{l}\text { Propylene } \\
\text { Ethylene } \\
\text { Isobutene }\end{array}$ & $\begin{array}{c}0.258 \pm 0.009 \\
0.751 \pm 0.038 \\
0.099 \pm 0.005 \\
\text { Average }\end{array}$ & $\begin{array}{l}(6.28 \pm 1.04) \times 10^{-12} \\
(6.40 \pm 1.02) \times 10^{-12} \\
(5.13 \pm 1.03) \times 10^{-12} \\
(\mathbf{5 . 9 3} \pm \mathbf{1 . 7 8}) \times \mathbf{1 0}^{-12}\end{array}$ \\
\hline EHX & $\begin{array}{l}\text { Propylene } \\
\text { Ethylene }\end{array}$ & $\begin{array}{c}0.259 \pm 0.004 \\
0.612 \pm 0.009 \\
\text { Average }\end{array}$ & $\begin{array}{l}(6.33 \pm 1.02) \times 10^{-12} \\
(5.21 \pm 0.78) \times 10^{-12} \\
(\mathbf{5 . 7 7} \pm \mathbf{1 . 2 9}) \times \mathbf{1 0}^{-\mathbf{1 2}}\end{array}$ \\
\hline $12 \mathrm{~EB}$ & $\begin{array}{l}\text { iso-Propyl acetate } \\
\text { Ethylene }\end{array}$ & $\begin{array}{c}0.406 \pm 0.011 \\
0.286 \pm 0.006 \\
\text { Average }\end{array}$ & $\begin{array}{l}(1.51 \pm 0.24) \times 10^{-12} \\
(2.43 \pm 0.37) \times 10^{-12} \\
(\mathbf{1 . 9 8} \pm \mathbf{0 . 3 9}) \times \mathbf{1 0}^{-\mathbf{1 2}}\end{array}$ \\
\hline$t \mathrm{~EB}$ & $\begin{array}{c}s e c \text {-Butyl acetate } \\
\text { Ethylene } \\
\text { Propylene }\end{array}$ & $\begin{array}{c}0.398 \pm 0.009 \\
0.190 \pm 0.007 \\
0.064 \pm 0.002 \\
\text { Average }\end{array}$ & $\begin{array}{l}(2.25 \pm 0.24) \times 10^{-12} \\
(1.62 \pm 0.25) \times 10^{-12} \\
(1.56 \pm 0.24) \times 10^{-12} \\
(\mathbf{1 . 8 1} \pm \mathbf{0 . 4 2}) \times \mathbf{1 0}^{-12}\end{array}$ \\
\hline$c \mathrm{~EB}$ & $\begin{array}{l}\text { iso-Propyl acetate } \\
\text { sec- Butyl acetate } \\
\text { Butane }\end{array}$ & $\begin{array}{c}0.518 \pm 0.012 \\
0.142 \pm 0.001 \\
0.745 \pm 0.022 \\
\text { Average }\end{array}$ & $\begin{array}{l}(1.93 \pm 0.16) \times 10^{-12} \\
(0.80 \pm 0.08) \times 10^{-12} \\
(1.77 \pm 0.19) \times 10^{-12} \\
(\mathbf{1 . 5 0} \pm \mathbf{0 . 2 6}) \times \mathbf{1 0}^{-12}\end{array}$ \\
\hline
\end{tabular}

To date, the rate coefficients of hundreds of new compounds have been studied under laboratory conditions with different atmospheric oxidants. However, there are still many compounds for which the database is still very scarce, as for cyclic ethers. There are several methodologies to estimate the rate coefficients towards $\mathrm{OH}$ radicals. One of them is quantum theoretical calculations useful for reactions, which are very difficult to study directly in the laboratory. Another approach is the Structure- 
195 Activity Relationship (SAR) method, which rely solely on the structure of the organic compounds and the effect of this structure on the reactivity. Both methodologies are critical to predict the chemical reactivity and physical behaviour of compounds where direct data are not available. The SAR estimation method applied for the epoxide type compounds studied in the present work treats the rate of abstraction from a group within an epoxide molecule. In the case of $\mathrm{H}$ atom abstraction from $\mathrm{C}-\mathrm{H}$ bonds, the calculation of the overall $\mathrm{H}$ atom abstraction rate constants is based upon the estimation of $-\mathrm{CH}_{3},-\mathrm{CH}_{2}$, $>\mathrm{CH}-$, group rate constants.

The $-\mathrm{CH}_{3},-\mathrm{CH}_{2^{-}}$, and $>\mathrm{CH}$ - group rate constants depend on the substituents around those groups.

For example, in the case of an $\alpha$ position: $k\left(\mathrm{CH}_{3}-\mathrm{X}\right)=k_{\text {prim }} \mathrm{F}(\mathrm{X}) ; k\left(\mathrm{X}-\mathrm{CH}_{2}-\mathrm{Y}\right)=k_{\text {sec }} \mathrm{F}(\mathrm{X}) \mathrm{F}(\mathrm{Y})$; and $k(\mathrm{X}-\mathrm{CH}(\mathrm{Y})(\mathrm{Z}))=k_{\text {tert }}$ $\mathrm{F}(\mathrm{X}) \mathrm{F}(\mathrm{Y}) \mathrm{F}(\mathrm{Z})$. Where $k_{\text {prim }}, k_{\text {sec }}$ and $k_{\text {tert }}$ are the rate constants per $-\mathrm{CH}_{3},-\mathrm{CH}_{2}$, and $>\mathrm{CH}$ - group for a "standard" substituent, $\mathrm{X}, Y$, and $Z$ are the substituent groups; and $F(X), F(Y)$, and $F(Z)$ are the corresponding substituent factors (Atkinson, 1987,

205 1986a, b). The validity and usefulness of a SAR depends on many factors, such as the amount and type of input data, reliability of prediction, scope of applicability, and ease of implementation (Vereecken et al., 2018).

The rate constants of the reactions with $\mathrm{OH}$ radicals obtained in this work were used to derive reactivity trends towards the $\mathrm{OH}$ radical. Also, five different approaches have been used in the SAR estimations in order to evaluate the most suitable method to predict the reactivity of this series of epoxides towards $\mathrm{OH}$ radicals. The results obtained are described in more 210 detail below.

For isomers it has been observed that within the experimental error limits, the rate coefficients for the reaction of trans-2,3epoxy butane with $\mathrm{OH}$ radicals are slightly different than that for cis-2,3-epoxybutane. Table 3 shows the result of the SAR calculations for the epoxide reactions by using different factors from the literature for the total rate constant estimation. Method (a) Kwok and Atkinson (1995) used the substituent factor $\mathrm{F}(-\mathrm{OR})=6$ to describe the effect of one or two $\alpha$-ether linkages, with

215 the influence of a $\beta$-ether linkage. Method (b) Calvert (2011) also took into consideration the influence of a $\beta$-ether linkage and a factor $\mathrm{F}(-\mathrm{OR})=4.13$. Method (c) Calvert (2015) is similar to method (a) and (b) but assuming a factor $\mathrm{F}(-\mathrm{OR})=8.4$. Comparing these approaches with the experimental results, for 1,2-epoxybutane the estimated value using the method (a) Kwok and Atkinson (1995) is the closest to the experimental value. However, it is not the case for cis / trans isomers where a small deviation is observed.

220 The SAR estimation using (e) Jenkin (2018) propose an improved new set of three rate coefficients for $\mathrm{H}$ atom abstraction for $\mathrm{C}$ atoms adjacent to ether linkages. These new sets of the rate coefficients are applied independently of neighbouring group substituent factors. Our experimental results show that the rate coefficient of 1,2-epoxybutane is lower than the rate coefficient calculated with this approach. The rate coefficient calculated for cyclohexene oxide with this approach is the lowest with respect to all experimental values and by other SAR estimation methods.

225 The influence of the ether group seems not be the same for epoxides of the same number of carbon atoms with differences in the symmetry. Factors like geometrical disposition and neighbour groups could explain the $\mathrm{H}$ atom abstraction in places far from the ether linkage. 
https://doi.org/10.5194/acp-2021-962

Preprint. Discussion started: 10 December 2021

(c) Author(s) 2021. CC BY 4.0 License.
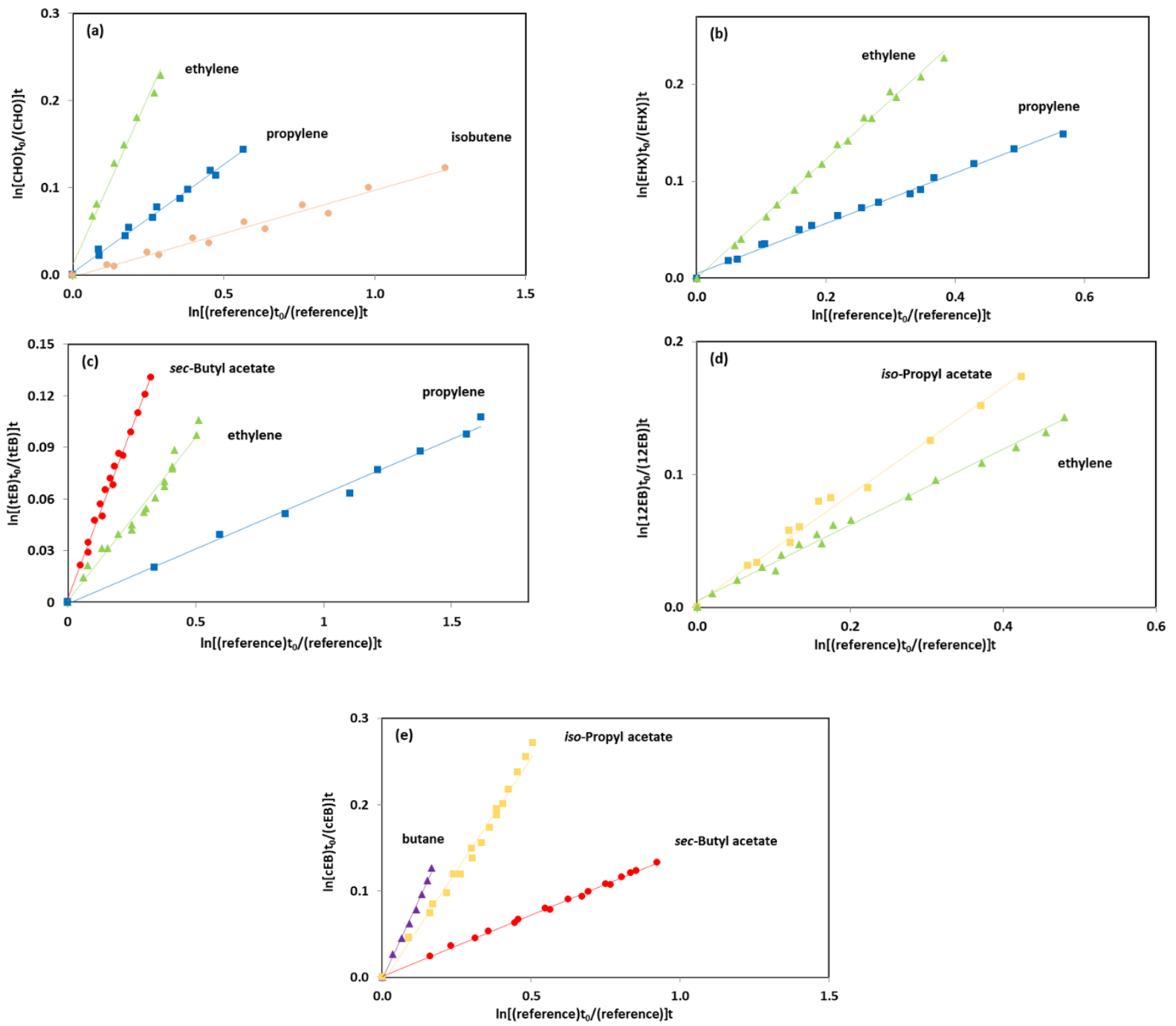

Figure 1. Kinetic data for the reaction of $\mathrm{OH}$ radicals with (a) $\mathrm{CHO}$; (b) $\mathrm{EHX}$; (c) $t \mathrm{~EB}$; (d) 12EB; (e) $c \mathrm{~EB}$ using ethylene, butane, sec-butyl acetate, iso-propyl acetate and propylene as reference compounds. 


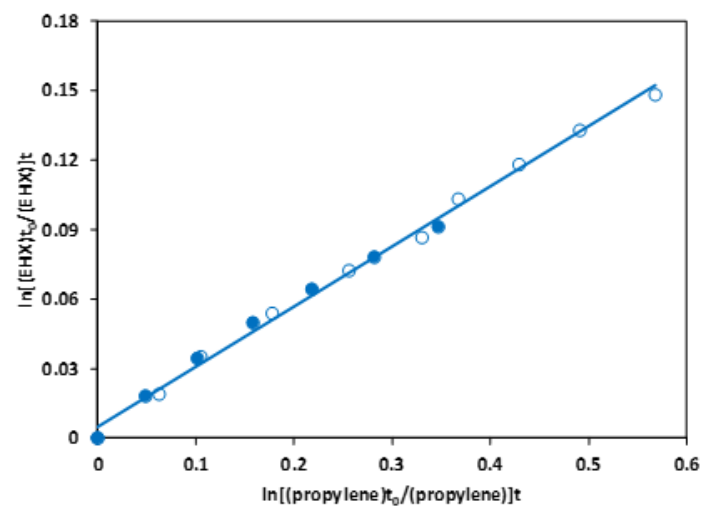

Figure 2. Kinetic data for the reaction of $\mathrm{OH}$ radicals with EHX using propylene as reference compound performed in $480 l$ reactor $(\bullet)$ and $1080 l$ reactor $(\circ)$.

In less substituted epoxides, such as propylene oxide the approaches presented by Kwok and Atkinson (1995), Calvert (2011), and Calvert (2015) are the closest to the experimental values determined in this work.

The SAR estimation (d) Middala (2011) proposed a corrected factor for ring strain, assuming that the effect of the presence of oxygen on the ring might have been underestimated. However, as shown in Table 3, the experimental data obtained in this work differ in most of the cases from the values predicted by SAR using this approach.

There are discrepancies between the values calculated by different approaches of the SAR estimation method, as is shown in Table 3. In addition, there is no SAR estimation method that consistently generates a value close to the experimental value for all compounds, which have been studied in the present work. These discrepancies had already been observed since the first 245 SAR approximations for cyclic ethers and they could be attributed to the limited database that still exists for this kind of compounds (Kwok and Atkinson, 1995; Jenkin et al., 2018). In general, all these approaches have been developed to fit the behaviour of cyclic alkanes, with one factor being attributed to ring strain and the presence of an ether group. 
https://doi.org/10.5194/acp-2021-962

Preprint. Discussion started: 10 December 2021

(c) Author(s) 2021. CC BY 4.0 License.

Table 3. Comparison of the rate coefficients for the reaction of $\mathrm{OH}$ radicals with the epoxides investigated in this study with the literature data and SAR predictions.

\begin{tabular}{|c|c|c|c|}
\hline Epoxide & $\mathbf{k}_{\mathrm{SAR}}$ & $\begin{array}{c}\mathbf{k}_{\text {Epoxide }} \\
\left(\mathrm{cm}^{3} \text { molecule }^{-1} \mathbf{s}^{-1}\right)\end{array}$ & Reference \\
\hline Cyclohexene Oxide & $\begin{array}{l}6.37 \times 10^{-12(a)} \\
6.14 \times 10^{-12(\mathrm{~b})} \\
6.31 \times 10^{-12(\mathrm{c})} \\
5.81 \times 10^{-12(\mathrm{~d})} \\
3.60 \times 10^{-12(\mathrm{e})}\end{array}$ & $\begin{array}{l}(5.93 \pm 1.78) \times 10^{-12} \\
(6.51 \pm 0.65) \times 10^{-12}\end{array}$ & $\begin{array}{c}\text { This work } \\
\text { (El Othmani et al., 2021a) }\end{array}$ \\
\hline $\begin{array}{c}\text { Ethylene Oxide } \\
\square \\
0\end{array}$ & $\begin{array}{l}2.80 \times 10^{-13(\mathrm{a})} \\
1.89 \times 10^{-13(\mathrm{~b})} \\
3.54 \times 10^{-13(\mathrm{c})} \\
0.77 \times 10^{-13(\mathrm{~d})} \\
3.09 \times 10^{-13(\mathrm{e})}\end{array}$ & $(0.88 \pm 0.25) \times 10^{-13}$ & (Calvert et al., 2011) \\
\hline Propylene Oxide & $\begin{array}{l}0.59 \times 10^{-12(\mathrm{a})} \\
0.46 \times 10^{-12(\mathrm{~b})} \\
0.67 \times 10^{-12(\mathrm{c})} \\
0.28 \times 10^{-12(\mathrm{~d})} \\
1.16 \times 10^{-12(\mathrm{e})}\end{array}$ & $\begin{array}{c}(0.49 \pm 0.52) \times 10^{-12} \\
(0.30 \pm 1.00) \times 10^{-12} \\
(0.47 \pm 0.24) \times 10^{-12}\end{array}$ & $\begin{array}{c}\text { (Wallington et al., 1988b) } \\
\text { (Middala et al., 2011) } \\
\text { (Virmani et al., 2020) }\end{array}$ \\
\hline$\overbrace{O}^{1,2 \text {-epoxyhexane }}$ & $\begin{array}{l}4.64 \times 10^{-12(\mathrm{a})} \\
4.48 \times 10^{-12(\mathrm{~b})} \\
4.15 \times 10^{-12(\mathrm{c})} \\
3.97 \times 10^{-12(\mathrm{~d})} \\
6.60 \times 10^{-12(\mathrm{e})}\end{array}$ & $(5.77 \pm 1.29) \times 10^{-12}$ & This work \\
\hline 1,2-epoxybutane & $\begin{array}{l}1.81 \times 10^{-12(\mathrm{a})} \\
1.65 \times 10^{-12(\mathrm{~b})} \\
1.83 \times 10^{-12 \odot} \\
1.45 \times 10^{-12(\mathrm{~d})} \\
3.69 \times 10^{-12(\mathrm{e})}\end{array}$ & $\begin{array}{l}(1.98 \pm 0.39) \times 10^{-12} \\
(1.90 \pm 0.67) \times 10^{-12} \\
(2.20 \pm 0.02) \times 10^{-12}\end{array}$ & $\begin{array}{c}\text { This work } \\
\text { (Wallington et al., 1988a) } \\
\text { (El Othmani et al., 2021b) }\end{array}$ \\
\hline $\begin{array}{l}\text { trans-2,3-epoxybutane } \\
\mathrm{H}_{3} \mathrm{C}\end{array}$ & $\begin{array}{l}0.92 \times 10^{-12(\mathrm{a})} \\
0.73 \times 10^{-12(\mathrm{~b})} \\
0.99 \times 10^{-12(\mathrm{c})} \\
0.49 \times 10^{-12(\mathrm{~d})} \\
1.61 \times 10^{-12(\mathrm{e})}\end{array}$ & $(1.81 \pm 0.42) \times 10^{-12}$ & This work \\
\hline cis-2,3-epoxybutane & $\begin{array}{l}0.92 \times 10^{-12(\mathrm{a})} \\
0.73 \times 10^{-12(\mathrm{~b})} \\
0.99 \times 10^{-12(\mathrm{c})} \\
0.49 \times 10^{-12(\mathrm{~d})} \\
1.61 \times 10^{-12(\mathrm{e})}\end{array}$ & $(1.50 \pm 0.26) \times 10^{-12}$ & This work \\
\hline
\end{tabular}

275 Calculated using the SAR estimation of (a) (Kwok and Atkinson, 1995), (b) (Calvert et al., 2011), (c) (Calvert et al., 2015), (d) (Middala et al., 2011), (e) (Jenkin et al., 2018). 
Table 4. Reactivity trends of epoxy compounds towards $\mathrm{OH}$ radicals compared with their homologous alkanes, cycloalkanes and ethers.

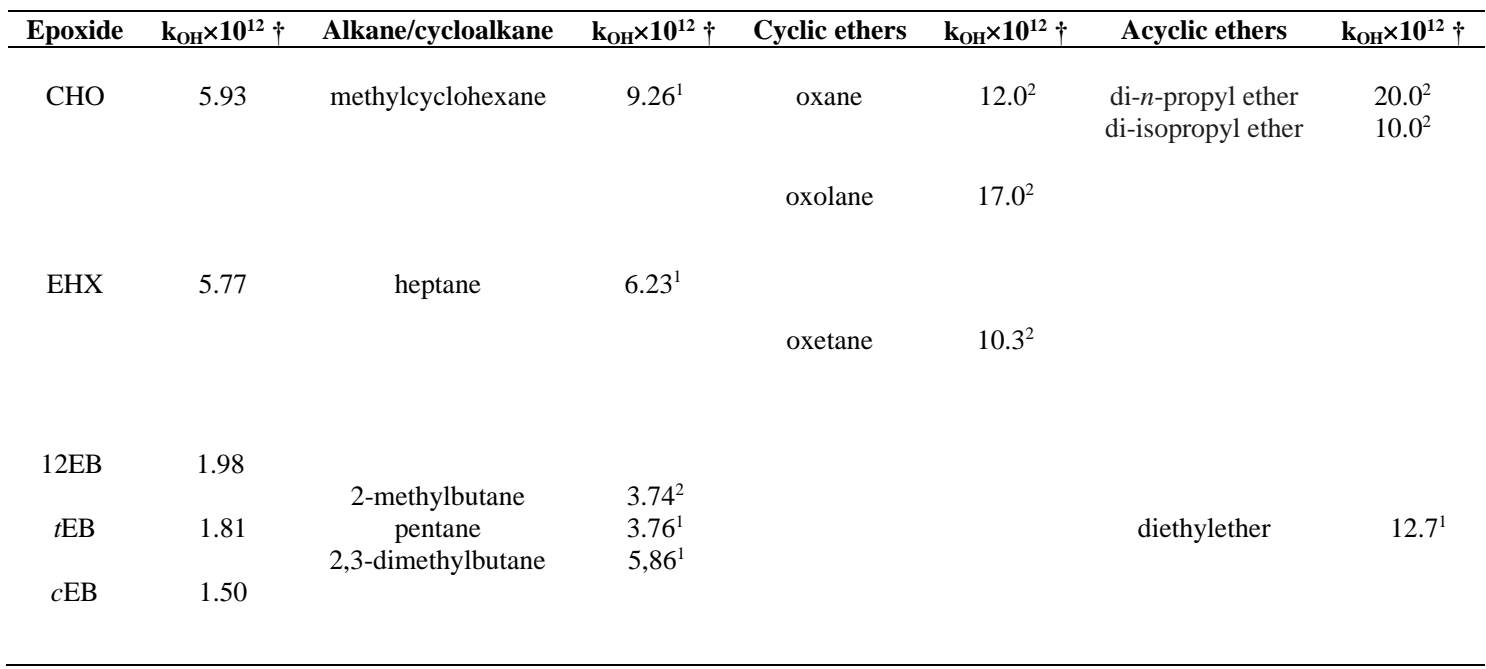

$280 \uparrow$ units: $\mathrm{cm}^{3}$ molecule $\mathrm{e}^{-1} \mathrm{~s}^{-1}$

${ }^{1}$ (McGillen et al., 2020); ${ }^{2}$ (Calvert et al., 2015) (Recomended values of the most recent revision of database for the kinetics of the gas-phase atmospheric reactions of organic compounds).

From Table 4 we can assess the influence of the ring size. In this way, epoxides are less reactive than their counterparts with

larger rings. (Tamres et al., 1954) stated that the electron ability in hydrogen bonding can act as a measure of the relative electron density. The very low electron donor ability of substituted ethylene oxides, compared with other cyclic ethers, in hydrogen bonding has already been shown in the past (Searles and Tamres, 1951; Searles et al., 1953). Thus, the oxygen in 3-membered ring ethers is more electronegative than in larger ring ethers or in acyclic ethers. This observation can be explained from Walsh's proposal for the structure of ethylene oxide and cyclopropane (Walsh, 1949). Walsh's model imply a high electron density in the centre of the three-membered rings, which suggests that the exterior of such rings would have a lower electron density than normal for the atoms involved. This effect is explained for strained systems where the hybridized orbitals employed for a bonding attain maximum overlap in such a way that altered valence angles "bent bonds" are realized. Because the Walsh model does not correspond to the ground state of cyclopropane/epoxide, the description of bent bonds for cyclopropane by the Förster-Coulson-Moffitt model (Förster, 1939; Coulson and Moffitt, 1949, 1947) is the most frequently considered one (Wiberg, 1996). More recently, the topological analysis of the electron density method (ED) is applied to describe the electron distribution within a compound (Kutzelnigg, 1993; Bader et al., 1994; Coppens, 2005; Koritsanszky and Coppens, 2001). However, the ED method provides information on concentration and depletion of electrons, but not on the pairing of electrons. In order to measure the electron pair localization the electron ability indicator (ELI) it is used (Kohout, 2004). A recent study presented by Grabowsky (2010), has introduced the ELI based on an X-ray diffraction experiment by means of the X-ray constrained wavefunction fitting procedure. The method was applied on a series of epoxides derivatives, and clearly indicated outwardly bent bonds according to the Förster-Coulson Moffit model. Also, this study shows that the maxima of deformation density and the valence shell charge concentrations (VSCCs) in the Laplacian maps are located clearly 
outside the bond axes for both the $\mathrm{C}-\mathrm{O}$ and $\mathrm{C}-\mathrm{C}$ bond, and there are no maxima inside the ring. The Förster-Coulson Moffit model makes use of hybrid orbitals with a relation between s- and $\mathrm{p}$ - character like $\mathrm{sp}^{2}$-hybridization. This conducts to an orbital overlapping outside the direct bond axis forming three $\sigma$-type bonds. The orbitals used in these exterior bent bonds of the ring are in a favourable position for some overlap with $p$-orbitals from adjacent atoms (Searles et al., 1953). The involvement of $\mathrm{sp}^{2}$-type orbitals in the epoxide ring instead of $\mathrm{sp}^{3}$ like in normal single bond suggests that the bonds are not saturated and can interact with $\pi$-electron systems (Grabowsky et al., 2010). Our recent study on the reactivity of a series of epoxides towards chlorine atoms in gas phase using quantum mechanical calculations agrees with these findings (Tovar et al., 2021). This structural effect has been observed also experimentally with cyclopropyl ketones (Rogers, 1947), $\alpha, \beta-$ epoxyketones (Walsh, 1949; Cromwell and Graff, 1952), ethylenimine ketones (Cromwell and Graff, 1952) and more recently in the acid catalysed ring opening of epoxides (Oshima et al., 2008). Moreover, there is some evidence of a conjugation of the epoxy ring with substituents using methods like UV spectroscopy, heat of combustion and MO calculations (Parker and Isaacs, 1959; Starit et al., 1964).

315 We can also evaluate the influence of the ring strain over the epoxides examined in the present study. As it is shown in Table 4, epoxides are less reactive towards $\mathrm{OH}$ radicals than the analogous alkanes. Besides, the rate coefficients for cycloalkanes are higher than for cyclohexene oxide. Grabowsky (2010), derived the experimental electron density of ethylene oxide from a multipole refinement of $100 \mathrm{~K} \mathrm{X}$-ray data and complemented by density-functional calculations at experimental and optimized geometry. This study found that despite the high strain in the three-membered ring of ethylene oxide, most atomic and bond topological properties do not differ from comparable fragments in unstrained molecules. Grabowsky (2010), concluded that the strained and unsaturated character of the epoxide ring is reflected in the populations of the bonds. As we discussed in Tovar et al. (2021), for the series of epoxides in the gas phase, the pseudo ethylenic character in the epoxy ring could explain the reactivity favouring the abstraction of $\mathrm{H}$ in $\beta$ position. The aforementioned factors can provide a possible explanation about the bad correlation between the different SAR estimations. The presented SAR estimations assume a factor for ether and another for ring strain. However, for a more accurate evaluation of the reactivity of epoxides, the structural properties and the unsaturated character of the ring should be considered. This could only be properly evaluated by means of theoretical calculations.

When comparing the reactivity of the 1,2-epoxyhexane with its corresponding aliphatic alkane, the presence of a 3-membered ring and oxygen in the molecule affect in a more subtle way the reactivity towards $\mathrm{OH}$ radicals. Moreover, when epoxides of four carbon atoms are compared with their corresponding aliphatic alkane, the presence of a 3-membered ring decreases the reactivity independently of the position of the substituents in the aliphatic chain. This can be seen by comparing the behaviour between cis/trans epoxy butane and 1,2-epoxy butane.

Finally, from Table 3 it can be observed that the consecutive addition of a $\mathrm{CH}_{2}$ group into the aliphatic chain increases the reactivity of the epoxides toward $\mathrm{OH}$ radicals.

335 This effect is summarised in Figure 3 where the rate constants for the reactions of the $\mathrm{OH}$ radical with the studied epoxides have been plotted as a function of the number of carbon atoms. Since SAR estimations do not match very well the experimental 
rate coefficients, the reactivity trends for the series of these compounds could add valuable information regarding the reactivity of epoxides. From Figure 3 it can be estimated that the rate coefficients for the reaction of epoxy pentanes with $\mathrm{OH}$ radicals should be in the range of $(2.0 \pm 5.7) \times 10^{-12} \mathrm{~cm}^{3}$ molecule $\mathrm{e}^{-1} \mathrm{~s}^{-1}$.

340 The comparison of the rate coefficients for the reaction of chlorine atoms with epoxides Tovar et al. (2021) with those obtained in this study for the reaction with $\mathrm{OH}$ radicals would show similar reactivity trends. A ratio of 1:3 between the rate coefficients for the reaction with $\mathrm{OH}$ radicals of $\mathrm{C} 4$-epoxides (EHX, $t \mathrm{~EB}$ and $c \mathrm{~EB}$ ) and $\mathrm{C} 6$-epoxides (CHO and $\mathrm{EHX}$ ) has been observed. This ratio has been also found by Tovar et al.(2021) for the epoxides series in the reaction with chlorine atoms. In this study, an experimental and theoretical structural analysis has been proposed considering the geometry of the molecule, in order to explain the reactivity of a series of epoxides.

Systematic theoretical data compilations could constitute a valuable tool in the development, evaluation, and validation of the SARs and kinetics models (Vereecken et al., 2018). As is shown in present work, although epoxides are rather simple structurally, there are still several discrepancies using different SARs estimation approaches for these species.

To improve the accuracy of SARs predictions, temperature-dependent data is also important, with special attention to the effects of functional groups (Vereecken et al., 2018). Some studies have evaluated the temperature dependence for 1,2epoxypropane and 1,2-epoxybutane towards $\mathrm{OH}$ radicals. Virmani et al. (2020) found for the reaction with 1,2-propylene oxide a very small (or possibly no) dependence on temperature within the temperature range between 261-355 K. El Othmani et al. (2021b) showed for the reaction with 1,2-epoxybutane a very weak negative temperature dependence at $\mathrm{T} \leq 285 \mathrm{~K}$ and a transition toward a positive temperature dependence at $\mathrm{T} \geq 295 \mathrm{~K}$. (El Othmani et al., 2021a) measured a stronger negative temperature dependence in the case of cyclohexene oxide. This behaviour could suggest the existence of van der Waals complexes that can play a role in the reaction mechanisms of epoxides at lower temperatures. More theoretical research is needed to further elucidate these findings.

Figure 3. Trends of the rate coefficients for the reaction of $\mathrm{OH}$ radicals with epoxides: effect of $\mathrm{CH}_{2}$ addition to the aliphatic chain.

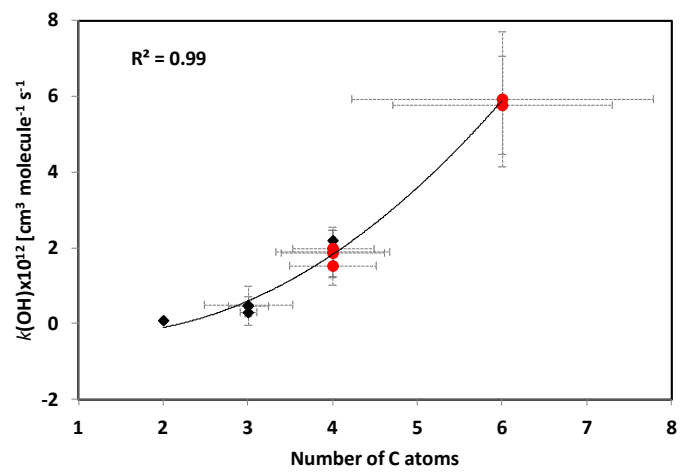




\section{Atmospheric implications}

Using the kinetic data obtained in the present work, in combination with daytime average radical concentrations, the estimation of the tropospheric lifetimes of the investigated compounds can be calculated using the expression:

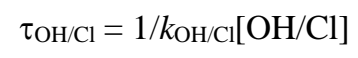

365 Therefore, for a globally averaged [OH] of $1 \times 10^{6} \mathrm{radicals} \mathrm{cm}^{-3}$ (Prinn et al., 1995), the atmospheric lifetimes for cyclohexene oxide, 1,2-epoxyhexane, 1,2-epoxybutane, trans-2,3-epoxybutane and cis-2,3-epoxybutane are estimated between 2 to 8 days, as shown in Table 5 .

According to the rate coefficients presented in Tovar et al. (2021) and considering an estimated atmospheric concentration [Cl] of $3 \times 10^{3}$ atoms $\mathrm{cm}^{-3}$ (Singh et al., 1996; Rudolph et al., 1996; Wingenter et al., 1996), an atmospheric lifetime between 16 and

37056 days has been calculated for the epoxides. Accordingly, the reaction with $\mathrm{OH}$ radicals is the primary sink for epoxides in the atmosphere under these conditions.

However, in highly polluted areas or coastal locations where $[\mathrm{Cl}]$ can be up to $5 \times 10^{4}$ atoms $\mathrm{cm}^{-3}$ (Hossaini et al., 2016; Spicer et al., 1998), Cl chemistry could contribute significantly to the removal of epoxides.

375 Table 5. Comparison of the atmospheric lifetimes of epoxides towards $\mathrm{OH}$ radicals and chlorine atoms.

\begin{tabular}{ccc}
\hline Epoxides & $\begin{array}{c}\tau_{\mathrm{OH}} \\
\text { (days) }\end{array}$ & $\begin{array}{c}\tau_{\mathrm{Cl}} \\
(\text { days })\end{array}$ \\
\hline cyclohexene oxide & 1.9 & $16.1^{*}$ \\
1,2-epoxyhexane & 2.0 & $21.8^{*}$ \\
1,2- epoxybutane & 5.8 & $45.8^{*}$ \\
trans-2,3-epoxybutane & 6.4 & $55.2^{*}$ \\
cis-2,3-epoxybutane & 7.7 & $55.8^{*}$ \\
\hline
\end{tabular}

* Calculated values using the rate coefficients of epoxides towards $\mathrm{Cl}$ atoms (Tovar et al., 2021).

With the reported lifetimes, the epoxides studied in the present work will contribute mainly to local air pollution. In laboratory and ambient SOA, epoxides are considered as potential precursors for sulphate esters, polyols, hydroxy nitrates and halides. Aerosol epoxide concentrations will be limited by the rates of the corresponding uptake process from the gas phase, which will be largely determined by the gas phase epoxide concentrations (Minerath and Elrod, 2009; Minerath et al., 2009). A study by (Lal et al., 2012) suggests that the heterogeneous reaction of some epoxides on acidic aerosols are faster and more efficient than gaseous reactions with atmospheric oxidants, and thus, these reactions could represent the major removal pathway for 
385 epoxides. Besides, in urban environments particle acidity can be significantly high, with a $\mathrm{pH}$ between $0-5$. Under such conditions, epoxides can react rapidly, and the reaction products of the heterogeneous reactions could contribute to the growth of SOA particles and to the possible modification of their physical and chemical properties (Zhang et al., 2007). Monitoring and evaluating the emissions of these compounds under different ambient conditions, as $\mathrm{pH}$ and different regimens of $\mathrm{NO}_{\mathrm{x}}$, is recommended in rural and urban locations.

\section{Conclusions}

The rate coefficients for the reaction of $\mathrm{OH}$ radicals with three different epoxides have been determined for the first time in this study. The rate coefficient for 1,2-epoxy butane and cyclohexene oxide are in very good agreement with previous studies (Wallington et al., 1988a; El Othmani et al., 2021b, a). A comparison of the reactivity trends from the gas-phase reaction of the epoxides obtained in this study showed a very good correlation with the reactivity trends of epoxides with chlorine atoms. Differences have been observed between the experimental $\mathrm{OH}$ rate coefficients and those obtained from SAR estimations. However, the values determined by the SAR method show some discrepancies dependent on the substituent factors, which were considered for the calculations. Such discrepancies could be explained by taking into consideration the structural effect of the ring acting in conjunction with the oxygen atom and the unsaturated character of the epoxy ring. From the atmospheric chemistry viewpoint, the rate coefficient from the present study would help to extend the database for the reaction of cyclic ethers under atmospheric conditions. Parallel to the present work, product studies of the reactions presented here have been undertaken, to delve a little deeper into the reaction mechanisms of these reactions.

Data availability. Data can be provided upon request to the corresponding author Carmen Maria Tovar carmen.tovar ramos@uni-wuppertal.de

405

Author contributions. CMT conducted the experiments and processed the data. CMT performed the data analysis. IB, IGB, and PW made revisions at different stages of the study. CMT prepared the paper with contributions from all co-authors.

Competing interests. The contact author has declared that neither they nor their co-authors have any competing interests.

Disclaimer. Publisher's note: Copernicus Publications remains neutral with regard to jurisdictional claims in published maps and institutional affiliations.

\section{Acknowledgement}

415 The authors acknowledge the financial support provided by the European Union's Horizon 2020 research and innovation programme, through the EUROCHAMP-2020 Infrastructure Activity Grant (grant agreement no. 730997). IGB acknowledges 
the PN-III-P4-ID-PCE-2016-4-0807 and PN-III-P2-2.1-PED-2019-4972 UEFISCDI projects. CMT is grateful for a PhD scholarship granted by FANTEL.

\section{References}

Almatarneh, M. H., Elayan, I. A., Altarawneh, M., and Hollett, J. W.: A computational study of the ozonolysis of sabinene, Theoretical Chemistry Accounts, 138, 30-30, https://doi.org/10.1007/s00214-019-2420-7, 2019a.

Almatarneh, M. H., Elayan, I. A., Abu-Saleh, A. A.-A. A., Altarawneh, M., and Ariya, P. A.: The gas-phase ozonolysis reaction of methylbutenol: A mechanistic study, International Journal of Quantum Chemistry, 119, e25888, https://doi.org/10.1002/qua.25888, 2019b.

Alvarado, A., Tuazon, E. C., Aschmann, S. M., Atkinson, R., and Arey, J.: Products of the gas-phase reactions of O $\left({ }^{3} \mathrm{P}\right)$ atoms and $\mathrm{O}_{3}$ with a-pinene and 1,2-dimethyl-1-cyclohexene, Journal of Geophysical Research: Atmospheres, 103, 25541-25551, https://doi.org/10.1029/98JD00524, 1998.

430 Andrea, K. A. and Kerton, F. M.: Iron-catalyzed reactions of $\mathrm{CO}_{2}$ and epoxides to yield cyclic and polycarbonates, Polymer Journal, 53, 29-46, https://doi.org/10.1038/s41428-020-00395-6, 2021.

IUPAC Task Group on Atmospheric Chemical Kinetic Data Evaluation: https://iupac-aeris.ipsl.fr/, last access: 26 October 2021.

Appaturi, J., Ramalingam, R., Gnanamani, M., Periyasami, G., Arunachalam, P., Adnan, R., Adam, F., Wasmiah, M., and Al-

435 Lohedan, H.: Review on Carbon Dioxide Utilization for Cycloaddition of Epoxides by Ionic Liquid-Modified Hybrid Catalysts: Effect of Influential Parameters and Mechanisms Insight, Catalysts, 11, https://doi.org/10.3390/catal11010004, 2021.

Atkinson, R.: Estimations of $\mathrm{OH}$ radical rate constants from $\mathrm{H}$-atom abstraction from $\mathrm{C}-\mathrm{H}$ and $\mathrm{O}-\mathrm{H}$ bonds over the temperature range 250-1000 K, International Journal of Chemical Kinetics, 18, 555-568, https://doi.org/10.1002/kin.550180506, 1986a.

440 Atkinson, R.: Kinetics and mechanisms of the gas-phase reactions of the hydroxyl radical with organic compounds under atmospheric conditions, Chemical Reviews, 86, 69-201, https://doi.org/10.1021/cr00071a004, 1986b.

Atkinson, R.: A structure-activity relationship for the estimation of rate constants for the gas-phase reactions of $\mathrm{OH}$ radicals with organic compounds, International Journal of Chemical Kinetics, 19, 799-828, https://doi.org/10.1002/kin.550190903, 1987.

445 Atkinson, R., Arey, J., Aschmann, S. M., and Tuazon, E. C.: Formation of O $\left({ }^{3} \mathrm{P}\right)$ atoms and epoxides from the gas- phase reaction of $\mathrm{O}_{3}$ with isoprene, Research on Chemical Intermediates, 20, 385-394, https://doi.org/10.1163/156856794X00388, 1994a.

Atkinson, R., Aschmann, S. M., Arey, J., and Tuazon, E. C.: Formation yields of epoxides and $\mathrm{O}\left({ }^{3} \mathrm{P}\right)$ atoms from the gas-phase reactions of $\mathrm{O}_{3}$ with a series of alkenes, International Journal of Chemical Kinetics, 26, 945-950, https://doi.org/10.1002/kin.550260908, 1994 b. 
Bader, R. F. W., Popelier, P. L. A., and Keith, T. A.: Theoretical Definition of a Functional Group and the Molecular Orbital Paradigm, 33, 620-631, https://doi.org/10.1002/anie.199406201, 1994.

Barnes, I., Becker, K. H., and Mihalopoulos, N.: An FTIR product study of the photooxidation of dimethyl disulfide, Journal of Atmospheric Chemistry, 18, 267-289, https://doi.org/10.1007/BF00696783, 1994.

Calvert, G., Atkinson, R., Kerr, A., Madronich, S., Moortgat, G., Wallington, J., and Yarwood, G.: The Mechanisms of Atmospheric Oxidation of the Alkenes, 2000.

Calvert, J., Mellouki, A., Orlando, J., Pilling, M., and Wallington, T.: Mechanisms of Atmospheric Oxidation of the Oxygenates, Oxford University Press, 2011.

Calvert, J. G., Orlando, J. J., Stockwell, W. R., and Wallington, T. J.: The Mechanisms of Reactions Influencing Atmospheric Ozone, Oxford University Press, 2015.

Coppens, P.: Charge Densities Come of Age, 44, 6810-6811, https://doi.org/10.1002/anie.200501734, 2005.

Coulson, C. A. and Moffitt, W. E.: Strain in Non-Tetrahedral Carbon Atoms, The Journal of Chemical Physics, 15, 151, https://doi.org/10.1063/1.1746450, 1947.

Coulson, C. A. and Moffitt, W. E.: I. The properties of certain strained hydrocarbons, The London, Edinburgh, and Dublin Philosophical Magazine and Journal of Science, 40, 1-35, https://doi.org/10.1080/14786444908561208, 1949.

Cromwell, N. H. and Graff, M. A.: Three-ring carbonyl hyperconjugation in cis and trans aryl-aroyl ethylene imines and related compounds, J. Org. Chem., 17, 414-425, https://doi.org/10.1021/jo01137a014, 1952.

Ehrenberg, L. and Hussain, S.: Genetic toxicity of some important epoxides, Mutation Research/Reviews in Genetic Toxicology, 86, 1-113, https://doi.org/10.1016/0165-1110(81)90034-8, 1981.

470 El Othmani, H., Ren, Y., Mellouki, A., Daële, V., and McGillen, M. R.: Gas-phase rate coefficient of OH + cyclohexene oxide measured from 251 to 373 K, Chemical Physics Letters, 783, 139056, https://doi.org/10.1016/j.cplett.2021.139056, 2021 a. El Othmani, H., Ren, Y., Bedjanian, Y., El Hajjaji, S., Tovar, C., Wiesen, P., Mellouki, A., McGillen, M. R., and Daële, V.: Gas-Phase Rate Coefficient of $\mathrm{OH}+1,2$-Epoxybutane Determined between 220 and $950 \mathrm{~K}$, ACS Earth and Space Chemistry, 5, 960-968, https://doi.org/10.1021/acsearthspacechem.1c00050, 2021b.

475 Fokin, V. V. and Wu, P.: Epoxides and Aziridines in Click Chemistry, in: Aziridines and Epoxides in Organic Synthesis, John Wiley \& Sons, Ltd, 443-477, https://doi.org/10.1002/3527607862.ch12, 2006.

Förster, T.: Die gegenseitige Beeinflussung der Valenzen im Kohlenstoffatom, 43B, 58-78, https://doi.org/10.1515/zpch-19394306, 1939.

Fuzzi, S., Baltensperger, U., Carslaw, K., Decesari, S., Denier van der Gon, H., Facchini, M. C., Fowler, D., Koren, I., Langford, B., Lohmann, U., Nemitz, E., Pandis, S., Riipinen, I., Rudich, Y., Schaap, M., Slowik, J. G., Spracklen, D. V., Vignati, E., Wild, M., Williams, M., and Gilardoni, S.: Particulate matter, air quality and climate: lessons learned and future needs, Atmospheric Chemistry and Physics, 15, 8217-8299, https://doi.org/10.5194/acp-15-8217-2015, 2015. 
Gao, S., Ng, N. L., Keywood, M., Varutbangkul, V., Bahreini, R., Nenes, A., He, J., Yoo, K. Y., Beauchamp, J. L., Hodyss, R. P., Flagan, R. C., and Seinfeld, J. H.: Particle Phase Acidity and Oligomer Formation in Secondary Organic Aerosol, Environmental Science \& Technology, 38, 6582-6589, https://doi.org/10.1021/es049125k, 2004.

Grabowsky, S., Jayatilaka, D., Mebs, S., and Luger, P.: The Electron Localizability Indicator from X-Ray Diffraction DataA First Application to a Series of Epoxide Derivatives, Chemistry - A European Journal, 16, 12818-12821, https://doi.org/10.1002/chem.201002061, 2010.

Guo, L., J. Lamb, K., and North, M.: Recent developments in organocatalysed transformations of epoxides and carbon dioxide into cyclic carbonates, Green Chemistry, 23, 77-118, https://doi.org/10.1039/D0GC03465G, 2021.

Hereijgers, B. P. C., Parton, R. F., and Weckhuysen, B. M.: Mechanistic insights in the olefin epoxidation with cyclohexyl hydroperoxide, Catalysis Science \& Technology, 2, 951-960, https://doi.org/10.1039/C2CY00455K, 2012.

Hossaini, R., Chipperfield, M. P., Saiz-Lopez, A., Fernandez, R., Monks, S., Feng, W., Brauer, P., and Glasow, R. von: A global model of tropospheric chlorine chemistry: Organic versus inorganic sources and impact on methane oxidation, Journal of Geophysical Research: Atmospheres, 121, 14,271-14,297, https://doi.org/10.1002/2016JD025756, 2016.

Jacobs, M. I., Darer, A. I., and Elrod, M. J.: Rate Constants and Products of the OH Reaction with Isoprene-Derived Epoxides, Environmental Science \& Technology, 47, 12868-12876, https://doi.org/10.1021/es403340g, 2013.

Jenkin, M. E., Young, J. C., and Rickard, A. R.: The MCM v3.3.1 degradation scheme for isoprene, Atmospheric Chemistry and Physics, 15, 11433-11459, https://doi.org/10.5194/acp-15-11433-2015, 2015.

500 Jenkin, M. E., Valorso, R., Aumont, B., Rickard, A. R., and Wallington, T. J.: Estimation of rate coefficients and branching ratios for gas-phase reactions of $\mathrm{OH}$ with aliphatic organic compounds for use in automated mechanism construction, Atmospheric Chemistry and Physics, 18, 9297-9328, https://doi.org/10.5194/acp-18-9297-2018, 2018.

Jiang, X., Tsona, N. T., Jia, L., Liu, S., Zhang, H., Xu, Y., and Du, L.: Secondary organic aerosol formation from photooxidation of furan: effects of NOx and humidity, Atmospheric Chemistry and Physics, 19, 13591-13609, https://doi.org/10.5194/acp19-13591-2019, 2019.

Kanakidou, M., Seinfeld, J. H., Pandis, S. N., Barnes, I., Dentener, F. J., Facchini, M. C., Dingenen, R. V., Ervens, B., Nenes, A., Nielsen, C. J., Swietlicki, E., Putaud, J. P., Balkanski, Y., Fuzzi, S., Horth, J., Moortgat, G. K., Winterhalter, R., Myhre, C. E. L., Tsigaridis, K., Vignati, E., Stephanou, E. G., and Wilson, J.: Organic aerosol and global climate modelling: a review, Atmospheric Chemistry and Physics, 5, 1053-1123, https://doi.org/10.5194/acp-5-1053-2005, 2005.

510 Klotz, B., Barnes, I., Becker, K. H., and Golding, B. T.: Atmospheric chemistry of benzeneoxide/oxepin, Journal of the Chemical Society, Faraday Transactions, 93, 1507-1516, https://doi.org/10.1039/A606152D, 1997.

Klotz, B., Barnes, I., Golding, B. T., and Becker, K.-H.: Atmospheric chemistry of toluene-1,2-oxide/2-methyloxepin, Physical Chemistry Chemical Physics, 2, 227-235, https://doi.org/10.1039/A908365K, 2000.

Kohout, M.: A measure of electron localizability, 97, 651-658, https://doi.org/10.1002/qua.10768, 2004. 
515 Kolb, H. C., Finn, M. G., and Sharpless, K. B.: Click Chemistry: Diverse Chemical Function from a Few Good Reactions, Angewandte Chemie International Edition, 40, 2004-2021, https://doi.org/10.1002/15213773(20010601)40:11\%3C2004::AID-ANIE2004\%3E3.0.CO;2-5, 2001.

Koritsanszky, T. S. and Coppens, P.: Chemical Applications of X-ray Charge-Density Analysis, Chem. Rev., 101, 1583-1628, https://doi.org/10.1021/cr990112c, 2001.

520 Kutzelnigg, W.: Book Review: Atoms in Molecules. A Quantum Theory. (International Series Monographs on Chemistry, Vol. 22). By R. F. W. Bader, 32, 128-129, https://doi.org/10.1002/anie.199301282, 1993.

Kwok, E. S. C. and Atkinson, R.: Estimation of hydroxyl radical reaction rate constants for gas-phase organic compounds using a structure-reactivity relationship: An update, Atmospheric Environment, 29, 1685-1695, https://doi.org/10.1016/13522310(95)00069-B, 1995.

525 Lal, V., Khalizov, A. F., Lin, Y., Galvan, M. D., Connell, B. T., and Zhang, R.: Heterogeneous Reactions of Epoxides in Acidic Media, The Journal of Physical Chemistry A, 116, 6078-6090, https://doi.org/10.1021/jp2112704, 2012.

Li, M., Liu, Y., and Wang, L.: Gas-phase ozonolysis of furans, methylfurans, and dimethylfurans in the atmosphere, Physical Chemistry Chemical Physics, 20, 24735-24743, https://doi.org/10.1039/C8CP04947E, 2018.

Lin, Y.-H., Zhang, H., Pye, H. O. T., Zhang, Z., Marth, W. J., Park, S., Arashiro, M., Cui, T., Budisulistiorini, S. H., Sexton, K. G., Vizuete, W., Xie, Y., Luecken, D. J., Piletic, I. R., Edney, E. O., Bartolotti, L. J., Gold, A., and Surratt, J. D.: Epoxide as a precursor to secondary organic aerosol formation from isoprene photooxidation in the presence of nitrogen oxides, Proceedings of the National Academy of Sciences, 110, 6718-6723, https://doi.org/10.1073/pnas.1221150110, 2013.

McGillen, M. R., Carter, W. P. L., Mellouki, A., Orlando, J. J., Picquet-Varrault, B., and Wallington, T. J.: Database for the kinetics of the gas-phase atmospheric reactions of organic compounds, Earth System Science Data, 12, 1203-1216, https://doi.org/10.5194/essd-12-1203-2020, 2020.

Middala, S., Campbell, S., Olea, C., Scruggs, A., and Hasson, A. S.: Kinetics and mechanism of the reaction of propylene oxide with chlorine atoms and hydroxy radicals, International Journal of Chemical Kinetics, 43, 507-521, https://doi.org/10.1002/kin.20580, 2011.

Minerath, E. C. and Elrod, M. J.: Assessing the Potential for Diol and Hydroxy Sulfate Ester Formation from the Reaction of Epoxides in Tropospheric Aerosols, Environmental Science \& Technology, 43, 1386-1392, https://doi.org/10.1021/es8029076, 2009.

Minerath, E. C., Schultz, M. P., and Elrod, M. J.: Kinetics of the Reactions of Isoprene-Derived Epoxides in Model Tropospheric Aerosol Solutions, Environmental Science \& Technology, 43, 8133-8139, https://doi.org/10.1021/es902304p, 2009.

545 Oshima, T., Asahara, H., Kubo, E., Miyamoto, S., and Togaya, K.: Conformational Effects in Acid-Mediated Ring Opening of Epoxides: A Prominent Role of the Oxirane Walsh Orbital, Organic Letters, 10, 2413-2416, https://doi.org/10.1021/ol800535c, 2008. 
Otto, H.-H. and Schirmeister, T.: Cysteine Proteases and Their Inhibitors, Chemical Reviews, 97, 133-172, https://doi.org/10.1021/cr950025u, 1997.

550 Parker, R. E. and Isaacs, N. S.: Mechanisms of Epoxide Reactions, Chem. Rev., 59, 737-799, https://doi.org/10.1021/cr50028a006, 1959.

Paulot, F., Crounse, J. D., Kjaergaard, H. G., Kürten, A., St Clair, J. M., Seinfeld, J. H., and Wennberg, P. O.: Unexpected epoxide formation in the gas-phase photooxidation of isoprene, Science (New York, N.Y.), 325, 730-733, https://doi.org/10.1126/science.1172910, 2009.

555 Paulson, S. E., Flagan, R. C., and Seinfeld, J. H.: Atmospheric photooxidation of isoprene part I: The hydroxyl radical and ground state atomic oxygen reactions, International Journal of Chemical Kinetics, 24, 79-101, https://doi.org/10.1002/kin.550240109, 1992.

Powers, J. C., Asgian, J. L., Ekici, Ö. D., and James, K. E.: Irreversible Inhibitors of Serine, Cysteine, and Threonine Proteases, Chemical Reviews, 102, 4639-4750, https://doi.org/10.1021/cr010182v, 2002.

560 Prinn, R. G., Weiss, R. F., Miller, B. R., Huang, J., Alyea, F. N., Cunnold, D. M., Fraser, P. J., Hartley, D. E., and Simmonds, P. G.: Atmospheric Trends and Lifetime of CH3CCI3 and Global OH Concentrations, Science, 269, 187-192, https://doi.org/10.1126/science.269.5221.187, 1995.

Rogers, M. T.: The Electric Moments and Ultraviolet Absorption Spectra of Some Derivatives of Cyclopropane and of Ethylene Oxide, Journal of the American Chemical Society, 69, 2544-2548, https://doi.org/10.1021/ja01202a081, 1947.

565 Rudolph, J., Koppmann, R., and Plass-Dülmer, Ch.: The budgets of ethane and tetrachloroethene: Is there evidence for an impact of reactions with chlorine atoms in the troposphere? Atmospheric Environment, 30, 1887-1894, https://doi.org/10.1016/1352-2310(95)00385-1, 1996.

Sandhiya, L., Kolandaivel, P., and Senthilkumar, K.: Mechanism and Kinetics of the Atmospheric Oxidative Degradation of Dimethylphenol Isomers Initiated by OH Radical, The Journal of Physical Chemistry A, 117, 4611-4626, https://doi.org/10.1021/jp3120868, 2013.

Schirmeister, T. and Klockow, A.: Cysteine Protease Inhibitors Containing Small Rings, Mini-Reviews in Medicinal Chemistry, 3, 585-596, 2003.

Searles, S. and Tamres, M.: Hydrogen Bond Formation with Saturated Cyclic Ethers1, Journal of the American Chemical Society, 73, 3704-3706, https://doi.org/10.1021/ja01152a041, 1951.

575 Searles, S., Tamres, M., and Lippincott, E. R.: Hydrogen Bonding Ability and Structure of Ethylene Oxides, Journal of the American Chemical Society, 75, 2775-2777, https://doi.org/10.1021/ja01107a517, 1953.

Shrivastava, M., Andreae, M. O., Artaxo, P., Barbosa, H. M. J., Berg, L. K., Brito, J., Ching, J., Easter, R. C., Fan, J., Fast, J. D., Feng, Z., Fuentes, J. D., Glasius, M., Goldstein, A. H., Alves, E. G., Gomes, H., Gu, D., Guenther, A., Jathar, S. H., Kim, S., Liu, Y., Lou, S., Martin, S. T., McNeill, V. F., Medeiros, A., de Sá, S. S., Shilling, J. E., Springston, S. R., Souza, R. a. F., Thornton, J. A., Isaacman-VanWertz, G., Yee, L. D., Ynoue, R., Zaveri, R. A., Zelenyuk, A., and Zhao, C.: Urban 
pollution greatly enhances formation of natural aerosols over the Amazon rainforest, Nature Communications, 10, 10461046, https://doi.org/10.1038/s41467-019-08909-4, 2019.

Singh, H. B., Thakur, A. N., Chen, Y. E., and Kanakidou, M.: Tetrachloroethylene as an indicator of low $\mathrm{Cl}$ atom concentrations in the troposphere, Geophysical Research Letters, 23, 1529-1532, https://doi.org/10.1029/96GL01368, 1996.

Skov, H., Benter, Th., Schindler, R. N., Hjorth, J., and Restelli, G.: Epoxide formation in the reactions of the nitrate radical with 2,3-dimethyl-2-butene, cis- and trans-2-butene and isoprene, Atmospheric Environment, 28, 1583-1592, https://doi.org/10.1016/1352-2310(94)90304-2, 1994.

Spicer, C. W., Chapman, E. G., Finlayson-Pitts, B. J., Plastridge, R. A., Hubbe, J. M., Fast, J. D., and Berkowitz, C. M.: Unexpectedly high concentrations of molecular chlorine in coastal air, Nature, 394, 353-356, https://doi.org/10.1038/28584, 1998.

Starit, L. A., Ketcham, Roger., Jambotkar, D., and Shah, V. P.: Three-Membered Rings. I. Conjugative Properties and Electrinic Spectra of Arylcyclopropanes, Oxiranes, and Thiiranes, J. Am. Chem. Soc., 86, 4628-4630, https://doi.org/10.1021/ja01075a022, 1964.

Stropoli, S. J., Miner, C. R., Hill, D. R., and Elrod, M. J.: Assessing Potential Oligomerization Reaction Mechanisms of Isoprene Epoxydiols on Secondary Organic Aerosol, Environmental Science \& Technology, 53, 176-184, https://doi.org/10.1021/acs.est.8b05247, 2019.

Tamres, M., Searles, S., Leighly, E. M., and Mohrman, D. W.: Hydrogen Bond Formation with Pyridines and Aliphatic Amines1, Journal of the American Chemical Society, 76, 3983-3985, https://doi.org/10.1021/ja01644a035, 1954.

Tovar, C. M., Haack, A., Barnes, I., Bejan, I. G., and Wiesen, P.: Experimental and theoretical study of the reactivity of a series of epoxides with chlorine atoms at $298 \mathrm{~K}$, Physical Chemistry Chemical Physics, 23, 5176-5186, https://doi.org/10.1039/D0CP06033J, 2021.

Vereecken, L.: Reaction Mechanisms for the Atmospheric Oxidation of Monocyclic Aromatic Compounds, vol. Volume 2, WORLD SCIENTIFIC, 377-527, https://doi.org/10.1142/9789813271838_0006, 2018.

Vereecken, L., Aumont, B., Barnes, I., Bozzelli, J. W., Goldman, M. J., Green, W. H., Madronich, S., Mcgillen, M. R., Mellouki, A., Orlando, J. J., Picquet-Varrault, B., Rickard, A. R., Stockwell, W. R., Wallington, T. J., and Carter, W. P. L.: Perspective on Mechanism Development and Structure-Activity Relationships for Gas-Phase Atmospheric Chemistry, International Journal of Chemical Kinetics, 50, 435-469, https://doi.org/10.1002/kin.21172, 2018.

Villanueva, F., Cabañas, B., Monedero, E., Salgado, S., Bejan, I., and Martin, P.: Atmospheric degradation of alkylfurans with chlorine atoms: Product and mechanistic study, Atmospheric Environment, 43, 2804-2813, 610 https://doi.org/10.1016/j.atmosenv.2009.02.030, 2009.

Virmani, A., Walavalkar, M. P., Sharma, A., Sengupta, S., Saha, A., and Kumar, A.: Kinetic studies of the gas phase reaction of 1,2-propylene oxide with the $\mathrm{OH}$ radical over a temperature range of 261-335 K, Atmospheric Environment, 237, 117709, https://doi.org/10.1016/j.atmosenv.2020.117709, 2020. 
Wallington, T. J., Dagaut, P., and Kurylo, M. J.: Correlation between gas-phase and solution-phase reactivities of hydroxyl radicals towards saturated organic compounds, J. Phys. Chem., 92, 5024-5028, https://doi.org/10.1021/j100328a039, $1988 \mathrm{a}$.

Wallington, T. J., Liu, R., Dagaut, P., and Kurylo, M. J.: The gas phase reactions of hydroxyl radicals with a series of aliphatic ethers over the temperature range 240-440 K, 20, 41-49, https://doi.org/10.1002/kin.550200106, 1988 b.

Wallington, T. J., Dagaut, P., Liu, R., and Kurylo, M. J.: The gas phase reactions of hydroxyl radicals with a series of esters over the temperature range 240-440 K, International Journal of Chemical Kinetics, 20, 177-186, https://doi.org/10.1002/kin.550200210, 1988c.

Walsh, A. D.: The structures of ethylene oxide, cyclopropane, and related molecules, Transactions of the Faraday Society, 45, 179-190, https://doi.org/10.1039/TF9494500179, 1949.

Wiberg, K. B.: Bent Bonds in Organic Compounds, Acc. Chem. Res., 29, 229-234, https://doi.org/10.1021/ar950207a, 1996.

625 Wingenter, O. W., Kubo, M. K., Blake, N. J., Smith, T. W., Blake, D. R., and Rowland, F. S.: Hydrocarbon and halocarbon measurements as photochemical and dynamical indicators of atmospheric hydroxyl, atomic chlorine, and vertical mixing obtained during Lagrangian flights, Journal of Geophysical Research: Atmospheres, 101, 4331-4340, https://doi.org/10.1029/95JD02457, 1996.

Zhang, F., Wang, Y., Zhang, X., Zhang, X., Liu, H., and Han, B.: Recent advances in the coupling of $\mathrm{CO}_{2}$ and epoxides into cyclic carbonates under halogen-free condition, Green Chemical Engineering, 1, 82-93, https://doi.org/10.1016/j.gce.2020.09.008, 2020.

Zhang, Q., Jimenez, J. L., Worsnop, D. R., and Canagaratna, M.: A Case Study of Urban Particle Acidity and Its Influence on Secondary Organic Aerosol, Environmental Science \& Technology, 41, 3213-3219, https://doi.org/10.1021/es061812j, 2007.

635 Zhou, S., Yeung, L. W. Y., Forbes, M. W., Mabury, S., and Abbatt, J. P. D.: Epoxide formation from heterogeneous oxidation of benzo[a]pyrene with gas-phase ozone and indoor air, Environmental Science: Processes \& Impacts, 19, 1292-1299, https://doi.org/10.1039/C7EM00181A, 2017.

Zou, B. and $\mathrm{Hu}, \mathrm{C} .:$ Halogen-free processes for organic carbonate synthesis from $\mathrm{CO}_{2}$, Current Opinion in Green and Sustainable Chemistry, 3, 11-16, https://doi.org/10.1016/j.cogsc.2016.10.007, 2017. 